\title{
A matrix for the evaluation of COVID-19 contact risk in healthcare workers: Technical note
}

\author{
Sağlık çalışanlarında COVID-19 temas riskinin değerlendirilmesi için bir matris: \\ Teknik not
}

\author{
Seyfi Durmaz Raika Durusoy \\ Ege University Faculty of Medicine, Department of Public Health, Izmir, Turkey
}

\begin{abstract}
The aim of this technical note is to propose a reliable, fast-adaptable and easy-to-use matrix that accurately classifies risk for contact tracing of healthcare workers with COVID-19 patients. The researchers have created a matrix with the support of the literature and their experience within the university hospital surveillance team. This matrix enables a detailed High / Medium / Low Risk classification of contacts of healthcare workers with COVID-19 cases, covering many different contact situations encountered in a university hospital. Three main headings have come to the fore in health worker contact risk classification: Differences caused by the ventilation of the environment: Indoors, well ventilated indoors, outdoors; direct contact or material sharing; aerosol generating procedure. The matrix is quickly adapted by surveillance team members and is easy to use.
\end{abstract}

Keywords: Healthcare workers; COVID-19; contact tracing; contact assessment; matrix.

\section{Öz}

Bu teknik notun amacı, sağlık çalışanlarında COVID-19 temas riskini doğru bir şekilde sınıflandıran güvenilir, hızlı uyarlanabilir ve kullanımı kolay bir matris önermektir. Araştırmacılar, üniversite hastanesi sürveyans ekibinin deneyimlerinden ve literatürlerden yararlanarak bir matris oluşturmuşlardır. Bu matris, bir üniversite hastanesinde sağlık çalışanlarının COVID-19 vakaları birçok farklı temas durumunu Yüksek / Orta / Düşük Risk olarak sınıflandırmasına olanak tanır. Sağılk çalışanı temas riski sınıflandırmasında üç ana başlık öne çıkmıştır: Ortamın havalandırılmasından kaynaklanan farkıııklar: İç mekân, iyi havalandırılan iç mekân, dış mekân; doğrudan temas veya ortak malzeme kullanımı; aerosol oluşturma prosedürü. Matris, sürveyans ekibi üyeleri tarafından hızla adapte olunmuş ve kullanımı kolaydır.

Anahtar Sözcükler: Sağlık çalışanları, COVID-19, temaslı takibi, temaslı değerlendirmesi, matris.

\section{INTRODUCTION}

The Occupational Health and Safety Unit (OHSU) conducts COVID-19 contact-tracing among the healthcare workers of Ege University Medical Faculty (EUMF) Hospital. The variety of the environment in terms of risky contacts in the workplace (open / well ventilated closed / closed / the environments where the aerosol-generating process is performed), the use of mask in the case and the healthcare worker, and the type of mask, together with the exposure time and distance (variety of distance), a need for a guide has arisen. In addition, it was necessary to evaluate the use of PPE and contact distance of the health worker together. When questioning direct contact with the cases or the use of common materials like computer keyboards, the need to question hand hygiene after contact was also required.

\footnotetext{
Corresponding author: Seyfi Durmaz

Ege University Faculty of Medicine, Department of Public

Health, Izmir, Turkey

E-mail: seyfi123@gmail.com

Application date: 08.03.2021

Accepted: 03.05.2021
} 
The aim of this technical note is to propose a reliable, fast-adaptable and easy-to-use matrix that accurately classifies the risk of contacts of healthcare workers with COVID-19 patients.

\section{Development of the matrix}

A matrix based on the guidelines of the Ministry of Health was developed by the researchers with the support of the literature and started to be used as of August 17 (Figure-1). The High / Medium / Low Risk classification has been updated (1-4). The first draft of the matrix, which was submitted for the approval of seven nurses, two occupational safety specialists and two medical doctors involved in contact determination studies, was updated in line with the recommendations and started to be implemented on August 24. At the end of the first month, the matrix was evaluated by the surveillance team and 7 experts (2 public health, 2 microbiology, 2 infectious diseases experts, 1 epidemiologist), and its application was continued following its approval.

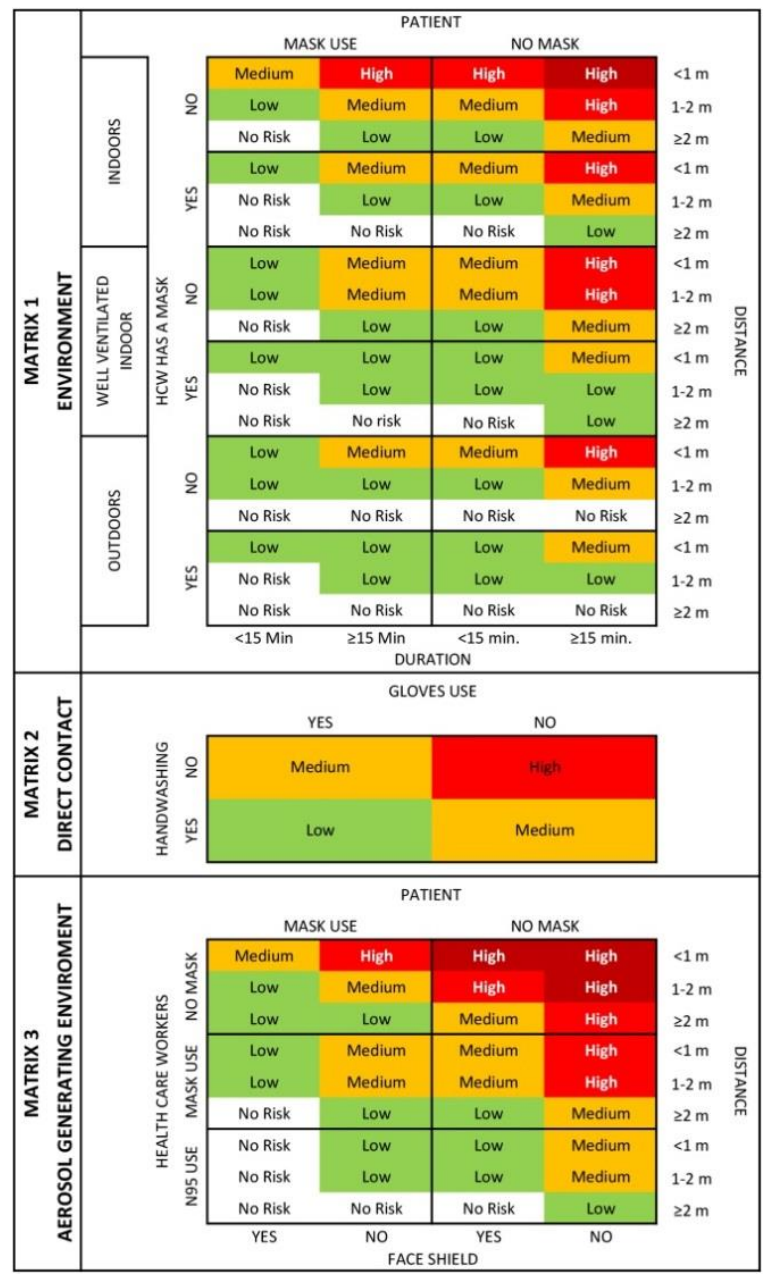

Figure-1. Matrix for the evaluation of Covid-19 contact risk in healthcare workers.

\section{DISCUSSION}

Three main headings came to the fore in health care workers contact risk classification.

\section{Differences caused by the ventilation of the environment: Indoors, well ventilated indoors, outdoors (Matrix 1)}

Indoors are more risky areas where it is difficult to keep the distance between people wide (5). Another possible situation that increases the risk is the longer stay together indoors (6). Well ventilation, essential for a healthy indoor climate, helps limit the spread of the SARS-CoV-2 virus (7). However, according to available data, the contamination potential is much lower outdoors than indoor environments, due to the turbulence levels found outdoors (6). In evaluating the contact of HCWs with COVID-19 cases, it was necessary to categorize the contact environment as closed / well ventilated indoor / outdoor. However, in situations where the same environment is shared, the risk is associated with many factors including ventilation of the environment, use of masks, distance and exposure time (8).

SARS-CoV-2 spreads between people who are in close contact with each other. A distance of at least 1 meter is recommended for COVID-19 patients to reduce the risk of infection when talking or coughing (9). However, there are also sources that suggest staying at least 2 meters away from other people even in open environments (5). In contact risk assessment, it is important to take into account that a physical distance of at least 1 meter reduces the risk of SARS-CoV-2 transmission, but 2 meters may be more effective, and the greater the distance, the more likely to be protected (10).

The risk of SARS-CoV-2 spread is determined by how closely the interaction with the COVID-19 case takes places and how long this interaction lasts. For healthcare workers, high-risk exposures are directly related to face-to-face contact lasting 15 minutes or longer $(1,8)$. Using the 15-minute contact time limit on the basis of evidence provides practicality in classification of contact risk (4). It should also be taken into account that the cumulative exposure time in repeated contacts affects the risk of transmission (11).

The mask worn by the person acts as a simple barrier to help prevent respiratory droplets from getting into the air and other people. The use of masks is particularly important in environments 
where people are close to each other or where social distance is difficult to maintain (10). Mask use details of both the HCW and the patient are important in determining the risk of COVID-19 exposure (12).

\section{Direct contact or material sharing (Matrix 2)}

A high-risk contact occurs when healthcare workers care for COVID-19 patients without or with inappropriate PPE. If hand hygiene has not been achieved after direct contact with the patient, with the patient's body fluids, or with the patient's contaminated environment, it is also within the scope of high-risk contact (1). This feature becomes more important when the case in contact is a colleague, so many different items likes pens and keyboards could be shared with the case in the two days before the symptoms or diagnosis.

\section{Aerosol generating procedures (AGP)}

\section{(Matrix 3)}

Coughing, sneezing, or laughing produce highvelocity gas clouds that contain respiratory droplets. This propels droplets farther than background airflow streams, transported over 2 meters in a short period of time. (8). Coughing, sneezing, or laughing are more likely to produce greater amounts of contagious respiratory aerosols than most procedures performed on patients (13). Performing aerosol generation procedures in healthcare settings or potentially elsewhere in closed, crowded, poorly ventilated environments increase the risk of infection (14). High risk contact can be considered when a healthcare worker is applying the procedure or is present in the environment without PPE or with inappropriate PPE during an AGP (1). The Ministry of Health's Assessment of the Contact Status of the Health Care Worker with the COVID-19 patient recommends the use of N95 masks and face shields or eyeglasses together in aerosol-generating procedures, considering the use of a medical mask instead of N95 or not using a face shield/eyeglasses as medium risk (2).

\section{SONUÇ}

However, there are difficulties in determining whether the reported transfers during AGPs are due to aerosols or other exposures (13). Another issue is that currently there is insufficient evidence to support the effectiveness of face shields for resource control. Therefore, face shields are not currently recommended to replace masks (13).

\section{Limitation}

Despite all this evidence, there are still situations where the matrix may be limited in its use. It should be noted that as the contact time increases in a poorly ventilated indoor, the importance of the distance and the protection of the mask decrease. Even if the contact time is short, how long the patient has been in the environment might be important and whether the patient is not wearing a mask as well. The total time of repeated exposure, whether it exceeds 15 minutes might be evaluated in detail by an experienced surveillance team. In addition, if there is more than one contact type, all of them should be evaluated separately and the HCWs followed-up according to the one with higher risk. It should not be forgotten that the evaluations rely on the self-reports of the person coming into contact with a COVID-19 case.

\section{Abbreviations}

AGP: Aerosol generating procedure

COVID-19: Coronavirus disease 2019

OHSU: Occupational Health and Safety Unit

EUMF: Ege University Medical Faculty

HCW: Healthcare worker

PCR: Polymerase chain reaction

PPE: Personal protective equipment

SARS-CoV-2: Severe acute respiratory syndrome coronavirus 2

WHO: World Health Organization

\section{Declarations}

\section{Conflict of interest}

The authors declare that they have no conflict of interest.

\section{Funding}

The author(s) received no financial support for the research.

\section{Authors' contributions}

$\mathrm{SD}$ and $\mathrm{RD}$ were involved in the development of the matrix and led the manuscript writing.

The manuscript was reviewed and authorized by the authors.

\section{Consent to participate}

The surveillance team and the experts consented to participate in the evaluation of the contact risk classification matrices. 


\section{Acknowledgements}

We would like to thank all physicians and EUMF employees who took part in the EUMF Hospital Surveillance Team during the pandemic period for their contribution. We would like to thank gratefully to the Microbiology Department's staff for conducting the high numbers of PCR tests of the hospital and for communicating us timely on the positive results so that we could trace their contacts earlier.

\section{References}

1. WHO. Prevention, identification and management of health worker infection in the context of COVID-19.

2. Republic of Turkey Ministry of Health. Contact Tracking, Epidemic Management, Patient Monitoring at Home and Fillation. 2020.

3. CDC. Interim U.S. Guidance for Risk Assessment and Work Restrictions for Healthcare Personnel with Potential Exposure to COVID-19 | CDC. 2020.

4. European Centre for Disease Prevention and Control. Contact tracing: public health management of persons, including healthcare workers, having had contact with COVID-19 cases in the European. Stokholm; 2020.

5. CDC. Deciding to Go Out | COVID-19 (Internet). (cited 2020 Nov 5). Available from: https://www.cdc.gov/coronavirus/2019-ncov/daily-life-coping/deciding-to-go-out.html

6. Bhagat RK, Davies Wykes MS, Dalziel SB, Linden PF. Effects of ventilation on the indoor spread of COVID19. J Fluid Mech. 2020; 903.

7. Morawska L, Tang JW, Bahnfleth W, Bluyssen PM, Boerstra A, Buonanno G, et al. How can airborne transmission of COVID-19 indoors be minimised? Vol. 142, Environment International. Elsevier Ltd; 2020. p. 105832.

8. Jones NR, Qureshi ZU, Temple RJ, Larwood JPJ, Greenhalgh T, Bourouiba L. Two metres or one: what is the evidence for physical distancing in covid-19? BMJ. 2020 Aug 25; 370: m3223.

9. WHO. Advice for the public (Internet). (cited 2020 Nov 5). Available from: https://www.who.int/emergencies/diseases/novel-coronavirus-2019/advice-for-public

10. Chu DK, Akl EA, Duda S, Solo K, Yaacoub S, Schünemann HJ, et al. Physical distancing, face masks, and eye protection to prevent person-to-person transmission of SARS-CoV-2 and COVID-19: a systematic review and meta-analysis. Lancet. 2020 Jun 27; 395 (10242): 1973-87.

11. Pringle JC, Leikauskas J, Ransom-Kelley S, Webster B, Santos S, Fox H, et al. COVID-19 in a Correctional Facility Employee Following Multiple Brief Exposures to Persons with COVID-19 - Vermont, July-August 2020. MMWR Morb Mortal Wkly Rep. 2020 Oct 30; 69 (43): 1569-70.

12. BC Ministry of Health. Coronavirus COVID-19 BC Heath Care Worker Exposures Risk Assessment Tool (Internet). 20AD (cited 2020 Nov 5). Available from: http://www.bccdc.ca/Health-ProfessionalsSite/Documents/COVID19_HCW_ExposuresRiskAssessmentTool.pdf.

13. Clinical Questions about COVID-19: Questions and Answers | CDC (Internet). (cited 2020 Nov 6). Available from: https://www.cdc.gov/coronavirus/2019-ncov/hcp/faq.html.

14. WHO. Transmission of SARS-CoV-2: implications for infection prevention precautions (Internet). 2020 (cited 2020 Oct 6). Available from: https://www.who.int/news-room/commentaries/detail/transmission-of-sars-cov-2implications-for-infection-prevention-precautions. 